Rafae Michalowski ${ }^{1}$

\title{
O bezumownym korzystaniu z gruntów znajdujących się w Zasobie Własności Rolnej Skarbu Państwa
}

Stosunkowo niedawno ustawodawca $\mathrm{w}$ znaczącym stopniu zmodyfikował i uzupełnił szereg uregulowań zawartych między innymi w ustawie o gospodarowaniu nieruchomościami rolnymi Skarbu Państwa, ${ }^{2}$ uchwalając ustawę z dnia 16 września 2011 r. o zmianie ustawy o gospodarowaniu nieruchomościami rolnymi Skarbu Państwa. ${ }^{3}$ Niektóre ze zmian wówczas wprowadzonych do u.g.n.r. dotyczyły zasadniczych aspektów materii normatywnej tam zawartej, w szczególności regulacji przetargu przy dysponowaniu gruntami wchodzącymi w skład Zasobu Własności Rolnej Skarbu Państwa. Nie można nie wspomnieć o dokonanej ustawą nowelizującą możliwości wyłączania przez Agencję Nieruchomości Rolnych do 30\% użytków rolnych z dzierżaw, która to regulacja doczekała się dość szybko omówienia w piśmiennictwie, ${ }^{4}$ budziła zresztą żywe emocje już na etapie sporządzania projektu ustawy - podjęcie tej problematyki w literaturze bez wątpienia uzasadnione było jego znaczącą praktyczną doniosłością dla funkcjonowania dzierżawców, którzy prowadzą działalność przy wykorzystaniu gruntów Zasobu. W niniejszym artykule prowadzone rozważania zostaną natomiast skoncentrowane na zagadnieniach szczegółowych związanych z nowym, wprowadzonym ustawą z dnia 16 września 2011 r. do u.g.n.r. uregulowaniem konsekwencji bezumownego korzystania z gruntów wchodzących w skład Zasobu Własności Rolnej Skarbu Państwa. Na tle wzmiankowanych powyżej, istotnych unormowań może się ono wydawać zagadnieniem błahym i niewartym szczególnej uwagi. Wbrew pozorom jednak ów problem ma relatywnie duże znaczenie dla działalności Agencji Nieruchomości Rolnych. Unormowanie to również budzić może bardzo poważne wątpliwości zarówno w aspekcie konstrukcyjnym, jak i w perspektywie jego spójności aksjologicznej z innymi rozwiązaniami prawnymi wchodzącymi w skład polskiego systemu prawnego. Stąd wypada podjąć próbę przynajmniej częściowego ich wyjaśnienia.

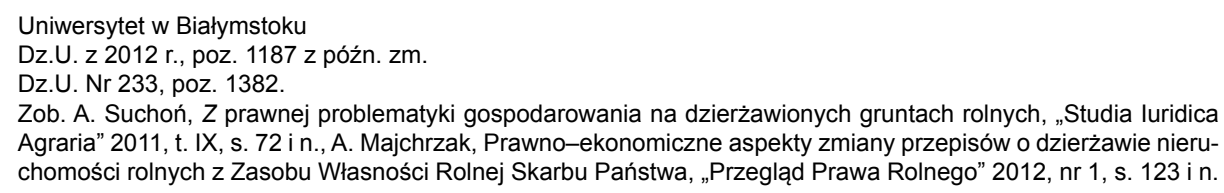

Zob. A. Suchoń, Z prawnej problematyki gospodarowania na dzierżawionych gruntach rolnych, „Studia luridica Agraria" 2011, t. IX, s. 72 i n., A. Majchrzak, Prawno-ekonomiczne aspekty zmiany przepisów o dzierżawie nieruchomości rolnych z Zasobu Własności Rolnej Skarbu Państwa, „Przegląd Prawa Rolnego” 2012, nr 1, s. 123 i n. 
Zgodnie z danymi pochodzącymi z okresu, w którym zaczęła obowiązywać szczególna regulacja wynagrodzenia za bezumowne korzystanie z nieruchomości ZWRSP, ${ }^{5}$ bezumownie wykorzystywane były grunty Zasobu o łącznej powierzchni około 24 tys. ha. ${ }^{6}$ Jest to znaczący areał, mając na uwadze, że rocznie sprzedaje się ok. 100 tys. ha gruntów ZWRSP.

U genezy stanów faktycznych bezumownego korzystania z nieruchomości ZWRSP stoją zdarzenia, które można podzielić na dwie zasadnicze grupy. Po pierwsze duża część osób wykorzystujących w ten sposób nieruchomości ZWRSP to byli dzierżawcy, których umowy zawarte z ANR wygasły, ale nie wydali oni nieruchomości wydzierżawiającemu po zakończeniu stosunku dzierżawy i w dalszym ciągu na nich gospodarują. Po drugie dochodzi nieraz do samowolnego objęcia w posiadanie gruntów przez osoby, którym nie przysługiwał do nich tytuł prawny wywodzony z dokonanej z ANR czynności prawnej. ${ }^{7}$ Sytuacje objęcia w posiadanie nieruchomości należących do drugiej klasy przypadków mają niekiedy wyjątkowo rażący charakter - bywa i tak, że w zorganizowany sposób dokonuje się „,zajazdów” na gruntach ZWRSP - wjeżdżając na nie pod osłoną nocy, obejmując we władanie i dokonując na nich prac polowych. ${ }^{8}$ Wskazuje się, że przyczyną tych „zajazdów” jest chęć uzyskania dopłat, do czego nie jest potrzebne legitymowanie się tytułem prawnym do nieruchomości. ${ }^{9}$

Takie tło towarzyszyło inicjatywie zmian normatywnych uwieńczonej wprowadzeniem do u.g.n.r. rozwiązania zawartego w art. 39b, będącego przedmiotem niniejszych rozważań. Podkreślić należy, że w toku prac Komisji Rolnictwa i Rozwoju Wsi nad projektami, które stanowiły podstawę dla uchwalonej dnia 16 września 2011 r. ustawy wprowadzającej art. 39b do u.g.n.r. jako motyw mający uzasadniać w tym zakresie interwencję ustawodawcy wskazywano właśnie na opisane powyżej okoliczności, w których osoby nieuprawnione władają nieruchomościami wchodzącymi w skład Zasobu - analizowane uregulowanie miałoby pełnić przede wszystkim funkcję prewencyjną, zapobiegając owym patologicznym zjawiskom. ${ }^{10}$

Regulacja problematyki bezumownego korzystania z nieruchomości z Zasobu jest bardzo lapidarna. Zgodnie z obowiązującym od 3 grudnia 2011 r. art. 39b ust. 1 u.g.n.r., osoba władająca bez tytułu prawnego nieruchomością wchodzącą w skład

$5 \quad$ Tj. według stanu na koniec $2011 \mathrm{r}$.

6 Raport z działalności Agencji Nieruchomości Rolnych na Zasobie Własności Rolnej Skarbu Państwa w 2011 r., s. 90, dostępny na stronie www.bip.anr.gov.pl

7 Zob. Najwyższa Izba Kontroli - Delegatura w Bydgoszczy, Ochrona gruntów Skarbu Państwa przed nieuprawnionym wykorzystywaniem (wystąpienie pokontrolne), s. 9, www.nik.gov.pl

8 Por. M. Felińska, Państwowe grunty traktują jak swoje, „Rolnik Dzierżawca” 2012 , nr 8 , s. 5 i n., A. Wrutniak, Ekonomia sobie, polityka sobie, „Rolnik Dzierżawca” 2013, nr 4, s. 16 i n.

9 Raport z działalności Agencji Nieruchomości Rolnych na Zasobie Własności Skarbu Państwa w 2012 r., s. 82 , dostępny na stronie www.bip.anr.gov.pl Wsi Sejmu VI kadencji dnia 29.07.2011 r., [w:] Biuletyn z posiedzenia Komisji Rolnictwa i Rozwoju Wsi, nr 5442/ VI, s. 5 i 7 , dostępny na stronie www.sejm.gov.pl 
Zasobu jest zobowiązana do zapłaty na rzecz Agencji wynagrodzenia za korzystanie z tej nieruchomości w wysokości stanowiącej 5-krotność wywoławczej wysokości czynszu, który byłby należny od tej nieruchomości, gdyby była ona przedmiotem umowy dzierżawy po przeprowadzeniu przetargu. Wysokość tego wynagrodzenia określa się na dzień, w którym Agencja zażądała jej wydania (ust. 2 art. 39b). Zgodnie natomiast $\mathrm{z}$ ust. 3 art. 39b, do roszczenia o wynagrodzenie za korzystanie bez tytułu prawnego z nieruchomości Zasobu nie stosuje się przepisów art. 224-231 kodeksu cywilnego, z wyłączeniem art. 229. Regulacja ta znajduje zastosowanie do stanów faktycznych bezumownego korzystania z nieruchomości z Zasobu, które zaistnieją po jej wejściu w życie, nie służą określeniu konsekwencji stanów faktycznych mających miejsce przed 3 grudnia 2011 r. $^{11}$

Takie uregulowanie problematyki wynagrodzenia za bezumowne korzystanie z nieruchomości ZWRSP przysparza wiele wątpliwości interpretacyjnych. W pierwszej kolejności należy zwrócić uwagę, że jak wiadomo, generalnie problematyka ta regulowania jest $\mathrm{w}$ kodeksie cywilnym $\mathrm{w}$ ramach konstrukcji roszczeń uzupełniających (art. 224-225 kc.). Unormowaniu roszczeń uzupełniających towarzyszy regulacja roszczeń związanych z rozliczeniem nakładów zawarta w art. 226 i 227 oraz jej specyficzny wariant ${ }^{12} \mathrm{w}$ postaci roszczenia o wykup w art. $231 \mathrm{kc}$. Zgodnie z przywołanymi przepisami kodeksu cywilnego, do roszczeń uzupełniających należą: roszczenie o wynagrodzenie za korzystanie z rzeczy, roszczenie o zwrot pożytków bądź ich równowartości oraz roszczenie o odszkodowanie za szkodę spowodowaną zużyciem rzeczy, jej pogorszeniem lub utratą. Sytuacja bezumownego posiadacza jest w perspektywie tych roszczeń zróżnicowana w zależności od tego, czy mamy do czynienia z posiadaczem w dobrej wierze, który dowiedział się o wytoczeniu przeciwko niemu powództwa o wydanie rzeczy, czy też posiadaczem w złej wierze. Ogólnie rzecz ujmując najlepszą pozycję ma posiadacz w dobrej wierze, najgorszą - posiadacz w złej wierze. Odnosząc to do kwestii samego wynagrodzenia za bezumowne korzystanie z rzeczy w ramach uregulowania roszczeń uzupełniających wskazać należy, że posiadacz w dobrej wierze nie jest w ogóle zobowiązany do jego zapłaty; posiadacz w dobrej wierze, który dowiedział się o wytoczeniu przeciwko niemu powództwa o wydanie rzeczy ma obowiązek do zapłaty wynagrodzenia od tej chwili; natomiast posiadacz w złej wierze ma obowiązek zapłaty wynagrodzenia również za okres sprzed wytoczenia powództwa o wydanie rzeczy.

Patrząc przez pryzmat modelowego, kodeksowego rozwiązania kwestii bezumownego korzystania $\mathrm{z}$ nieruchomości na przepis art. 39b u.g.n.r. nie sposób nie zwrócić uwagi na różnice między tymi uregulowaniami. W treści u.g.n.r. mówi się

11 Zob. uzasadnienie wyroku Sądu Najwyższego z dnia 21 listopada 2011 r., sygn. akt IV CSK 161/11.

12 Por. A. Kubas, Budowa na cudzym gruncie, Warszawa 1972, s. 27 i n.; ogólnie o kwestii roszczeń uzupełniających oraz roszczeń z tytułu nakładów zob. zamiast wielu: E. Gniewek, [w:] System Prawa Prywatnego. t. III. Prawo rzeczowe, E. Gniewek (red.), Warszawa 2013, s. 900 i n. 
ogólnie o osobie władającej bezumownie nieruchomością. Inaczej niż w kodeksie cywilnym, nie czyni się $\mathrm{w}$ warstwie terminologicznej rozróżnienia na posiadacza samoistnego i zależnego (zob. art. 230 k.c.). Co więcej, sam termin „osoba władająca” mógłby wydawać się prima facie nieadekwatny, skoro „,bezprzymiotnikowy” władający to również dzierżyciel, a więc osoba władająca rzeczą za kogoś innego (zob. art. $338 \mathrm{kc}$.) - jednak względy racjonalnej wykładni wsparte wnioskami wynikającymi z kontekstu systemowego (odpowiednie uregulowania w kodeksie cywilnym) pozwalają na przyjęcie, że chodzi tu o osoby władające dla siebie - o posiadaczy - samoistnych i zależnych (ci ostatni to w odniesieniu do roszczeń ANR - przede wszystkim dzierżawcy, którzy nie wydali gruntu po wygaśnięciu stosunku dzierżawy, o ile nie zmienili oni sposobu wykonywania władztwa na znamionujące posiadanie samoistne). W tej kwestii nie ma tu zasadniczej różnicy. Na marginesie analizy warstwy terminologicznej zwrócić trzeba uwagę na sporą językową niezręczność w sposobie sformułowania ust. 1 art. 39b. Mowa jest tam o „osobie władającej nieruchomością wchodzącą w skład Zasobu bez tytułu prawnego". Z takiego ujęcia wynikać może dość zaskakujący wniosek, że zwrot „bez tytułu prawnego” nie dotyczy władającego, ale Zasobu (,,nieruchomość wchodząca w skład Zasobu bez tytułu prawnego"), co jednak z racji na jego absurdalność należy odrzucić. Dużo lepiej jednak pod względem redakcyjnym byłoby, gdyby zwrot „bez tytułu prawnego” ujęty został bezpośrednio po zwrocie „osoba władająca”.

Znacznie poważniejsze wątpliwości przy wykładni art. 39b budzi inna kwestia dotycząca wyznaczenia kręgu adresatów normy z niego wynikającej - a mianowicie, jakie znaczenie dla wyznaczenia klasy osób zobowiązanych do zapłaty wynagrodzenia w 5-krotnej wysokości wywoławczej wartości czynszu ma to, czy władający nieruchomością z Zasobu jest posiadaczem w dobrej, czy też w złej wierze. W perspektywie jednej z podstawowych reguł wykładni wyrażonej w paremii lege non distinguente - nasuwa się wniosek, że zobowiązany do zapłaty represyjnej stawki wynagrodzenia jest każdy posiadacz, niezależnie od tego, czy jego posiadaniu towarzyszy dobra, czy zła wiara. Wniosek ten wspiera argument z treści ust. 3 art. 39b, który wyłącza zastosowanie odpowiednich artykułów kodeksu cywilnego, przewidujących wszak zróżnicowanie pozycji bezumownego posiadacza w tym zakresie. Pomijając inne wątpliwości wyłaniające się na tle interpretacji art. 39b ust. 3, o których mowa będzie w dalszej części niniejszego artykułu wydaje się dość oczywiste, że na gruncie wykładni językowej oraz reguł systemowych oznacza to uniezależnienie powstania powinności wynikającej z art. 39b ust. 1 od przymiotu dobrej bądź złej wiary bezumownego posiadacza nieruchomości Zasobu.

W tym kontekście należy odnieść się do opinii, wyrażonej w toku prac Sejmu towarzyszącej usprawiedliwieniu wprowadzenia do u.g.n.r. regulacji art. 39b, zgodnie z którą wysoka stawka wynagrodzenia za bezumowne korzystanie z nieruchomości z Zasobu, o której mowa w tym przepisie dotyczyć ma tylko osób, któ- 
re odmawiają ANR wydania nieruchomości. ${ }^{13}$ Jeśli rozumieć to stwierdzenie w ten sposób, że obowiązek zapłaty takiego represyjnego wynagrodzenia dotyczy jedynie tych posiadaczy, którzy nie wydają nieruchomości po uprzednim skierowaniu do nich takiego żądania przez ANR, to taka interpretacja art. 39b nie znajduje należytego uzasadnienia w jego treści. Jest tak dlatego, że adresat obowiązku zapłaty 5-krotności wartości czynszu oraz okoliczności, w których powstaje ten obowiązek są w całości określone w ust. 1 art. 39b, który w ogóle nie przewiduje jako przesłanki jego powstania wezwania do zwrotu gruntu i faktu niezastosowania się przez władającego do tego żądania. Żądanie zwrotu gruntu przewiduje natomiast ust. 2 art. 39b, ale jedynie w kontekście wskazania chwili, w której określa się wysokość wynagrodzenia - innymi słowy dotyczy chwili, według której określa się pułap czynszu stanowiącego podstawę do wyznaczenia wysokości wynagrodzenia, a w żadnej mierze nie odnosi się do kwestii wskazania, kto jest adresatem normy prawnej wyrażonej w art. 39b u.g.n.r. ani nie ustanawia przesłanek powstania tego obowiązku. Stąd jedyną możliwą konstatacją na gruncie językowej wykładni art. 39b jest zaprezentowane już stwierdzenie, że każdy posiadacz bezumowny nieruchomości z ZWRSP, niezależnie od przymiotu dobrej czy złej wiary, jest zobowiązany do zapłaty dla ANR wynagrodzenia wg 5-krotnej stawki wywoławczej wartości czynszu.

Ta w sumie dość oczywista w perspektywie językowej wykładni art. 39b konkluzja nie przystaje w żadnej mierze do modelowego, kodeksowego rozwiązania, w ramach którego uwzględnia się uzasadnione aksjologicznie zróżnicowanie obowiązku zapłaty wynagrodzenia za bezumowne korzystanie z nieruchomości z ZWRSP uzależnionego od przymiotu dobrej/złej wiary posiadacza. Co więcej, o czym już była mowa - przy dobrej wierze posiadacza ów obowiązek nie powstaje w ogóle. Doprawdy trudno doszukać się adekwatnego uzasadnienia mającego fundament $\mathrm{w}$ akceptowanych przez prawodawcę wartościach dla zastosowanego $\mathrm{w}$ tej mierze rozwiązania $\mathrm{w}$ u.g.n.r. Nie uzasadnia go w szczególności publiczny charakter mienia Zasobu - akurat w tym aspekcie brak jest jakichkolwiek racji celowościowych, aby doszukiwać się usprawiedliwienia zróżnicowania pozycji posiadaczy rolnego mienia państwowego ${ }^{14}$ i należącego do innych kategorii podmiotów. Być może motywem wprowadzenia uregulowania art. 39b przewidującego obowiązek zapłaty wynagrodzenia nie nawiązując do dobrej bądź złej wiary posiadacza jest to, że na gruncie regulacji kodeksowej to na właścicielu dochodzącym roszczeń uzupełniających spoczywa ciężar dowodu złej wiary posiadacza. Wszak treść art. 7 kc. sprawia, że to osoba występująca z roszczeniem o wynagrodzenie za bezumowne korzy-

Tak Prezes ANR Tomasz Nawrocki na posiedzeniu Komisji Rolnictwa i Rozwoju Wsi dnia 27.07.2011 r.; Biuletyn z posiedzenia Komisji Rolnictwa i Rozwoju Wsi, nr 5442/VI, s. 5.

14 Zauważmy, że brak takich uregulowań prawnych w odniesieniu do nieruchomości skarbowych i samorządowych nie pozostających w ZWRSP - tam zastosowanie znajdą przepisy kodeksu cywilnego. Stąd mielibyśmy do czynienia z nieuzasadnionym zróżnicowaniem regulacji również $\mathrm{w}$ ramach różnych reżimów gospodarowania publicznymi nieruchomościami rolnymi oraz nieruchomościami o innym charakterze. 
stanie z nieruchomości musi udowodnić brak dobrej wiary po stronie pozwanego. ${ }^{15}$ Natomiast konstrukcja art. 39b u.g.n.r. sprawia, że kwestia dobrej bądź złej wiary posiadacza jest indyferentna, stąd ANR ma lepszą sytuację w procesie niż podmiot dochodzący takich roszczeń na zasadach ogólnych. Przypuszczenia te są o tyle uzasadnione, że aby uniknąc sygnalizowanych konsekwencji wystarczyłoby zastosować bardzo prosty zabieg - wprost powiązać w treści art. 39b obowiązek zapłaty podwyższonego wynagrodzenia z posiadaniem w złej wierze, co jednak wiązałoby się ze wskazanymi potencjalnymi trudnościami dla ANR w sferze postępowania dowodowego.

Kolejny problem wyłaniający się w toku interpretacji art. 39b u.g.n.r. dotyczy sformułowania ust. 3 tego artykułu, który stanowi, iż w odniesieniu do roszczenia o bezumowne korzystanie z nieruchomości nie stosuje się art. 224-231 kc. z wyłączeniem jego art. 229. Otóż wątpliwości budzi ustalenie, jaki jest rzeczywisty zakres przepisów kodeksu cywilnego ulegających wyłączeniu od stosowania jak i czego dokładnie wyłączenie to dotyczy (jak rozumieć zwrot „do roszczenia o wynagrodzenie"), gdyż przepis ust. 3 art. 39b jest w tym zakresie wyjątkowo niejasny. Obie te kwestie pozostają ze sobą w ścisłym związku i wymagają dokonania równoległej ich analizy.

Jeśli chodzi o określenie rzeczywistego zakresu odesłania, mając na uwadze wskazane w art. 39b ust. 3 przepisy kodeksu cywilnego (czyli - których zastosowanie jest wyłączone) należy wskazać, co następuje. Ustawodawca wskazał, że do roszczenia ANR nie stosuje się żadnego z przepisów kodeksowych dotyczących roszczeń uzupełniających i roszczeń z tytułu nakładów z wyjątkiem art. 229 k.c. określającego termin przedawnienia. Jeśli u.g.n.r. stanowi, że nie stosuje się tych przepisów do roszczenia o wynagrodzenie, to należy ustalić po pierwsze, w jakiej relacji pozostają poszczególne przepisy kodeksu cywilnego do tego roszczenia i po drugie, jak należy rozumieć ów zwrot - „do roszczenia o wynagrodzenie (...) nie stosuje się...”. Wskazanie na roszczenie o wynagrodzenie, gdyby rozumieć ten zwrot ściśle, dotyczyć może treści tego roszczenia, podmiotów, którym przysługuje oraz względem których jest skierowane, terminu jego przedawnienia, okoliczności powodujących jego powstanie, zmianę treści oraz jego wygaśnięcie. W tym kontekście niemal zupełne wyłączenie zastosowania tych przepisów kodeksowych nie jest zrozumiałe. O ile teoretycznie może ono mieć sens w odniesieniu do kodeksowej regulacji samego wynagrodzenia za bezumowne korzystanie przy założeniu, że uregulowanie w u.g.n.r. jest kompletne (z wyłączeniem problematyki przedawnienia), to w odniesieniu do regulacji pozostałych roszczeń uzupełniających oraz roszczeń z tytułu nakładów już nie. Bo jaki sens ma dokonywanie wyłączenia zastoso- 
wania przepisów, które ściśle rzecz biorąc, do samego roszczenia o wynagrodzenie za bezumowne korzystanie nie mogą mieć zastosowania? Weźmy pod uwagę dokonane w art. 39b ust. 3 wyłączenie zastosowania art. 231 kc. Dotyczy on roszczeń o przeniesienie własności, które przysługuje bądź posiadaczowi samoistnemu gruntu (art. 231 § 1), bądź właścicielowi (art. 231 § 2). Posiłkując się ustaleniami doktryny i orzecznictwa ${ }^{16}$ poczynionymi na gruncie regulacji ustawy z dnia 21 sierpnia 1997 r. o gospodarce nieruchomościami, ${ }^{17}$ które w tej mierze należy uznać za aktualne również na tle regulacji zasad obrotu państwowymi nieruchomościami rolnymi wyłączenie to jest niezrozumiałe, ponieważ w sytuacji, gdy zasadą przy przenoszeniu własności nieruchomości publicznych jest zawarcie umowy sprzedaży poprzedzanej trybem przetargowym, roszczenie o wykup z art. $231 \S 2$ dla właściciela ${ }^{18} \mathrm{w}$ ogóle nie powstaje bez jakiejkolwiek wyraźnej dodatkowej interwencji ustawodawcy w tym zakresie. Również wyłączenie zastosowania przepisów art. 226 i $227 \mathrm{kc}$. nie ma sensu patrząc przez pryzmat wskazanego wyżej sposobu rozumienia zwrotu „do roszczenia o wynagrodzenie za korzystanie” zawartego w art. 39b ust. 3, ponieważ te przepisy kodeksu cywilnego dotyczą odrębnego segmentu roszczeń przysługujących nie właścicielowi, ale bezumownie korzystającemu z nieruchomości - w doktrynie wskazuje się, że są to roszczenia ,przeciwstawne” roszczeniom uzupełniającym właściciela, w tym roszczeniu o wynagrodzenie. ${ }^{19}$

Stąd można by poprzestać na stwierdzeniu, że w świetle wskazanego powyżej sposobu rozumienia tego zwrotu, wyłączenie zawarte w art. 39b ust. 3 nie da się traktować literalnie jako wyeliminowanie wszystkich wskazanych tam przepisów w odniesieniu do dookreślenia roszczenia o wynagrodzenie, ale jedynie jako ogólne postanowienie proklamujące odrębność roszczenia określonego w art. 39b ust. 1 u.g.n.r., rzeczywiście wyłączające jedynie regulację kodeksową dotyczącą samego wynagrodzenia za bezumowne korzystanie z nieruchomości (art. 224 oraz $225 \mathrm{kc}$. w odpowiednim zakresie) nie ingerując w pozostałą materię roszczeń uzupełniających oraz roszczeń z tytułu nakładów. Takie wyniki wykładni art. 39b ust. 3 nie mogą jednak zostać uznane za satysfakcjonujące patrząc na nie przez pryzmat całościowej spójności unormowania rozliczeń pomiędzy posiadaczem gruntu a ANR. Doszłoby bowiem do tego, że wynagrodzenie za bezumowne korzystanie z nieruchomości jest należne na zasadach wyłącznie określonych w art. 39b u.g.n.r., a więc przy zrównanej pozycji posiadaczy w dobrej i w złej wierze nakładając na nich taką samą dolegliwość w postaci konieczności uiszczenia podwyższonego wynagrodzenia za bezumowne korzystanie z nieruchomości, podczas gdy pozostałe roszczenia

16 Por. S. Rudnicki, [w:] G. Bieniek, S. Rudnicki, Nieruchomości. Problematyka prawna, Warszawa 2013, s. 35 oraz wyrok WSA w Olsztynie z dnia 9 września 2010 r., sygn. akt II SA/OI 662/10, Lex nr 754024.

17 Dz.U. z 2010 r. Nr 102, poz. 651 z późn. zm.

18 Na gruncie u.g.n.r. chodzi, co oczywiste, o Agencję działającą jako ustawowy powiernik Skarbu Państwa.

19 E. Gniewek, [w:] System prawa prywatnego..., op. cit., s. 901. 
na zasadach ogólnych ulegałyby zróżnicowaniu w zależności od dobrej bądź złej wiary posiadacza.

Taka wykładnia jednak łatwo może być zakwestionowania w oparciu o zarzut, że w sposób dowolny, sprzeczny z wyraźną deklaracją prawodawcy, czyni - z jasnego językowo zwrotu wyrażającego wolę rzeczywistego wyeliminowania od zastosowania wszystkich wskazanych przepisów - w dużej mierze czczą deklarację pozbawioną znaczenia normatywnego. Dlatego można by podjąć próbę innej jeszcze interpretacji art. 39b ust. 3, w którym jednak zwrot „roszczenie o wynagrodzenie za korzystanie bez tytułu prawnego z nieruchomości Zasobu" musi zostać zredefiniowany w stosunku do pierwotnie przyjętego dla potrzeb niniejszych rozważań. Otóż należałoby go traktować jako znaczący tyle co „stan faktyczny uzasadniający powstanie roszczenia o wynagrodzenie za bezumowne korzystanie z nieruchomości”. Jakie łączą się z tym konsekwencje? Takie elastyczne, szerokie ujęcie pozwalałoby na przyjęcie, że wszędzie tam, gdzie potencjalnie może zaistnieć roszczenie o wynagrodzenie, a więc zasadniczo w każdym przypadku bezumownego korzystania z nieruchomości z Zasobu, powstaje roszczenie $\mathrm{z}$ art. 39b ustawy, przy jednoczesnym wyłączeniu w tych okolicznościach zastosowania wszystkich wskazanych $\mathrm{w}$ art. $39 \mathrm{~b}$ ust. 3 przepisów kodeksu cywilnego. Jednak nawet dla najbardziej zagorzałego zwolennika ścisłej, językowej wykładni tych przepisów chyba nie przyszłoby do głowy, aby twierdzić, że w stanach faktycznych, w których mamy do czynienia $\mathrm{z}$ bezumownym korzystaniem $\mathrm{z}$ nieruchomości Zasobu, jedynym roszczeniem, które wówczas powstaje jest roszczenie o wynagrodzenie za bezumowne korzystanie z nieruchomości, zaś nie powstają (zarówno dla posiadacza i ANR) jakiekolwiek inne roszczenia związane $\mathrm{z}$ pogorszeniem albo utratą rzeczy, rozliczeniem pożytków czy też nakładów. Innymi słowy - że z racji wyłączenia zastosowania odnośnych przepisów kodeksu cywilnego ani Agencji nie przysługują jakiekolwiek roszczenia z tytułu pogorszenia stanu nieruchomości ani dotyczące pożytków, zaś posiadaczowi nie przysługują jakiekolwiek roszczenia z tytułu nakładów. Jednak wobec wyłączenia art. 224-231 kc. należałoby poszukiwać podstawy dla roszczeń posiadacza oraz ANR w przepisach o bezpodstawnym wzbogaceniu oraz w przepisach o czynach niedozwolonych. Generalnie nie budzi większych wątpliwości, że przepisy art. 224 i nast. k.c. w zakresie wyznaczonym przez ich zakres zastosowania wyłączają przepisy o bezpodstawnym wzbogaceniu. ${ }^{20}$ Jednak, wobec wyłączenia zastosowania art. 224-231 kc. w analizowanym wariancie interpretacyjnym przez art. 39b ust. 3 u.g.n.r., otwiera się pole dla zastosowania tychże. W szczególności w odniesieniu do określenia losów nakładów poczynionych na bezumownie wykorzystywanym gruncie należałoby sięgnąć do art. 408 kc., który reguluje te kwestie w ramach reżimu bezpodstawnego wzbogacenia, a którego zastosowanie w odniesieniu do stosunków między właścicielem a posiadaczem wyłącza się w sytuacjach typo- 
wych ze względu na konkurencję tego roszczenia z art. 226 i 227 kc. Należy zauważyć, że na gruncie art. 408 kc. pozycja wzbogaconego jest zróżnicowana w zależności od tego, czy wiedział on, czy korzyść mu się należy, czy też nie. ${ }^{21}$ Stąd również i w tym wariancie interpretacyjnym art. 39b ust. 3 tak jak i w poprzednio analizowanym mielibyśmy do czynienia z bezwzględnym, uniezależnionym od przesłanek podmiotowych obowiązkiem zapłaty podwyższonego wynagrodzenia, gdy w przypadku innych roszczeń będących tu „substytutami” roszczeń określonych w art. 224 i nast. kc. opartych na przepisach o bezpodstawnym wzbogaceniu i odpowiedzialności deliktowej, ocena ta byłaby bardziej zniuansowana, ${ }^{22}$ co świadczy o dużej niespójności uregulowania. Ponadto zupełne wyłączenie zastosowania art. $231 \mathrm{kc}$. oznaczałoby, że w sytuacji wskazanej w jego $§ 1$ samoistnemu posiadaczowi w dobrej wierze nie przysługiwałoby względem Agencji roszczenie o przeniesienie własności działki zajętej przez wzniesiony budynek. Na gruncie u.g.n. dopuszczalność powstania takiego roszczenia nie budzi wątpliwości. Brak jakichkolwiek racji systemowych i celowościowych, aby różnicować w tym zakresie regulację obrotu skarbowymi nieruchomościami rolnymi i zurbanizowanymi, zwłaszcza że takie wyłączenie zastosowania przepisu będącego źródłem niekwestionowanego w doktrynie wyjątku od przetargowego trybu zbywania nieruchomości publicznych dokonywałoby się jedynie ubocznie, przy okazji regulowania dość istotnej, ale jednak szczegółowej kwestii, nie związanej z trybem dysponowania mieniem Zasobu, która nie powinna wpływać na rozwiązania dotyczące obrotu nieruchomościami z Zasobu.

Poczynione rozważania, a właściwie zupełnie nieracjonalne, niespójne systemowo oraz nie dające się zaakceptować w perspektywie aksjologicznej wyniki wykładni opierającej się przede wszystkim na językowych jej regułach same w sobie są wystarczającym argumentem uzasadniającym stwierdzenie, że uzyskane w ten sposób wyniki powinny ulec znaczącej korekturze, mając na uwadze pespektywę celowościową analizowanej regulacji. Stąd trzeba by przyjąć, pomimo braku punktu zaczepienia dla takiej interpretacji w literalnym brzmieniu przepisu, że adresatem obowiązku zapłaty wynagrodzenia, o którym mowa w art. 39b u.g.n.r. są jedynie posiadacze (samoistni i zależni) w złej wierze ${ }^{23}$ oraz że w zakresie nie dotyczącym wy-

21 Por. R. Trzaskowski, [w:] Kodeks cywilny. Komentarz. Księga trzecia. Zobowiązania. Tom I, J. Gudowski (red.), Warszawa 2013, s. 318 i n.

22 Ponieważ uzależniona byłaby od spełnienia przesłanek poszczególnych uregulowań, które byłyby podstawą dla wysuwanych roszczeń odszkodowawczych (zwłaszcza w odniesieniu do roszczenia przysługującego ANR z tytułu pogorszenia rzeczy) czy też z bezpodstawnego wzbogacenia. Przywołane uregulowanie art. 408 kc. jest tego dobitnym przykładem.

23 Argumenty funkcjonalne, a zwłaszcza wzgląd na motywy przyświecające prawodawcy ustanawiającemu regulację art. 39b u.g.n.r. oraz argument systemowy oparty na konstrukcji art. 224 i nast. kc. sprzeciwiają się jednakowemu traktowaniu na gruncie art. 39b posiadacza w złej wierze i posiadacza w dobrej wierze, który dowiedział się o wytoczeniu powództwa o wydanie gruntu bądź został wezwany przez ANR do jego wydania. Stąd należy uznać, że art. 39b dotyczy jedynie posiadaczy w złej wierze, tylko w odniesieniu do nich wyłączone jest stosowanie art. $224 \mathrm{kc}$. i nast. co powoduje, że posiadacze w dobrej wierze, którzy dowiedzieli się o wytoczeniu przeciwko nim powództwa o wydanie rzeczy muszą uiścić wynagrodzenie za bezumowne korzystanie z nieruchomości z Zasobu na ogólnych zasadach kodeksowych, a więc w wysokości odpowiadającej zazwyczaj adekwatnej stawce czynszu dzierżawnego stosowanego w obrocie, nie zaś w podwyższonej, pięciokrotnej wysokości. 
nagrodzenia za bezumowne korzystanie z nieruchomości Zasobu należnego od nich nie wyłączono zastosowania odpowiednich przepisów kodeksu cywilnego dotyczących pozostałych roszczeń uzupełniających oraz roszczeń z tytułu nakładów. Ten wariant odpowiada również najpełniej motywom wprowadzenia omawianej regulacji do u.g.n.r. Oczywiście, należy zdawać sobie sprawę z jego dyskusyjności, jednak nie sposób przeoczyć, że w teorii prawa dopuszcza się przełamanie uzyskanych wyników wykładni językowej w razie, gdy jest to niezbędne dla zachowania założeń dotyczących spójności systemu wartości prawodawcy. ${ }^{24}$ Temu zaś służy ostatni wariant wykładni art. 39b u.g.n.r.

24 M. Zieliński, Wykładnia prawa. Zasady. Reguły. Wskazówki, Warszawa 2002, s. 228-229. 
O bezumownym korzystaniu z gruntów znajdujących się w Zasobie Własności Rolnej...

REMARKS ON USING OF AGRICULTURAL LAND FROM AGRICULTURAL RESOURCES OF THE STATE TREASURY WITHOUT CONTRACTUAL BASIS

Key words: Agricultural Property Agency, Agricultural Resources of the State Treasury, possessor

The article deals with the issue of using on a non-contract basis properties from the Agricultural Resources of the State Treasury managed by Agricultural Property Agency. Above-mentioned problem is regulated in the art. 39b of the act on management of agricultural property owned by State Treasury. General provisions regarding to the problem of payment for using thing without contractual basis is governed by Civil Code, but the legislator introduced that special provision referring to the legal consequences of possessing state-owned properties. Author states that the result of the literal interpretation of art. $39 \mathrm{~b}$ leads to unjust results and violates axiological values associated with this regulation. There are no axiological justification to assume that the possessor acting in good faith should be treated in the same way as possessor acting in bad faith. Only the result of functional interpretation is acceptable, because it leads to conclusion that possessor acting in good faith is not obliged to pay for using property without contractual basis. 